\title{
An educational approach to leprosy control: an evaluation of knowledge, attitudes and practice in two poor localities in Bombay, India
}

\author{
N CROOK,${ }^{*}$ R RAMASUBBAN,$\dagger$ A SAMY $\ddagger$ \\ $\& \mathrm{~B} \mathrm{SINGH} \dagger$ \\ * School of Oriental and African Studies, University of London, \\ Thornhaugh Street, Russell Square, London WC1H OXG, England; \\ †Centre for Social and Technological Change, 10 Zeba Corner, \\ Sherly Rajan Road, Bandra, Bombay 400 050, India; and $\ddagger$ Alert- \\ India, 6/B Mukhyadhyapak Bhavan, Sion (West), Bombay 400022 , \\ India
}

Accepted for publication 1 February 1991

\begin{abstract}
Summary Based on the hypothesis that a systematic, carefully planned educational approach to leprosy would yield results in terms of knowledge, attitudes and case presentation superior to those of the established and traditional mass survey method, ALERT-India launched a programme in S ward of Bombay in February 1985, to compare the two. An intensive programme of health education, using trained teams, was carried out in one zone of this ward over a period of 12 months. Eight months later, mass survey work (as used routinely in previous years and on a country-wide basis) was carried out in an adjacent zone. In 1987, the Centre for Social and Technological Change in Bombay, in association with the School of Oriental and African Studies, University of London, was requested to evaluate the effect of the above educational approach in terms of knowledge, attitudes and practice in both the trial and control zones. Other aspects of this experimental approach, including its cost and effectiveness in identifying cases of leprosy, will be published separately. The design of the 'KAP' evaluation and the social and environmental controls introduced in the statistical analysis are described. The results pointed to a considerable degree of ignorance about leprosy as a disease (and its treatment) in both the study and the control zones. Knowledge about early symptoms was particularly weak and on all aspects scores for women were invariably lower than men. General education enhanced the absorption of specific knowledge, and the education of children compensated adequately for lack of parental education in this respect. Overall the evaluation indicated that the intensive educational approach was superior to the survey approach in terms of improving knowledge, attitudes and practice.
\end{abstract}




\section{Introduction}

ALERT-India is a voluntary organization committed to the control of leprosy in the eastern suburbs of Bombay, by identifying and treating early cases of leprosy, and by enlightening the public on various aspects of the disease. ${ }^{1}$ The prevalence rate for leprosy in Bombay is believed to be between 10 and 15 cases per 1000 population, ${ }^{2-4}$ and the city is listed as a hyperendemic district by the National Leprosy Eradication Programme. ${ }^{5}$ The neighbourhoods covered by ALERT consist mainly of slum settlements, with an aggregate population of some 400,000 . For case detection the main tool has been the door-to-door survey, during which some educational material is disseminated, mainly in the form of leaflets. The educational component is backed up by slide or film shows at local schools, factories, and community meeting places.

A major drawback of the mass survey method is that it is time consuming. Further, as the approach is one of 'seeking out' the patient, and following him or her up to ensure completion of the required treatment, patient conviction and motivation are sometimes lacking. Finally, as an educational tool, the method has disadvantages. Whatever education is imparted mainly reaches the patients as a result of treatment and follow-up. Non-patients receive only perfunctory information at the time of the initial door-to-door examination, and the community-level programmes are spread too thinly over the population, whose attendance at these events is sometimes meagre.

\section{Methodology}

In 1985 ALERT launched an experimental approach designed to eliminate these drawbacks. Over a 12-month period a well-defined slum community (referred to as L zone) was visited by a health education team, which held a film or slide show at the end of every road or lane. Leaflets were distributed door-to-door. Posters and stickers were widely displayed and talks and exhibitions held at the community level. In short, the approach was one of intensive education, rather than mass survey and more peripheral education.

This paper reports the results of a subsequent evaluation of knowledge, attitudes and practice carried out in 1987 in L zone by the Centre for Social and Technological Change. ${ }^{6}$ A questionnaire was presented to 200 residents; they were selected so that there should be 100 patients and 100 nonpatients. Similarly, in another community (referred to as $\mathrm{M}$ zone), where a mass survey had been conducted in 19858 months after the experiment in L zone, a further sample of 200, similarly selected, was used as a control. The questionnaire was designed to test the public's basic knowledge about, attitudes towards, and behavioural practice of relevance to the disease. Items for the test of knowledge consisted of a range of symptoms, the bacteriological origin of the disease, the transmission mechanism, and the curability and methods involved. Knowledge of symptoms was graded from basic knowledge (the existence of a skin patch), through an intermediate level (for example, absence of sensation on the patch) to a higher level (for example absence of hair or sweating on the patch). Use of a questionnaire to elicit responses on questions such as these may not be fully reliable in a semi-literate population. However, in Bombay the illiterate are more familiar with the ways of the modern world than they would be in a remote rural village, and in our experience are 
unusually articulate. Furthermore, the investigators were paramedics working for ALERT, who would have some familiarity with testing opinions and knowledge in this population.

\section{Results}

In both zones the amount of knowledge absorbed was distressingly low: only $30 \%$ of respondents could recall the symptom classified as basic, roughly the same proportion recalled symptoms at the intermediate level, and $17 \%$ at the higher level. However, the difference between the experimental and control zones was brought out fairly clearly, with the experimental zone yielding a higher proportion of respondents with pertinent knowledge at all levels (a statistically significant difference at the two higher levels, as illustrated for the medium level in Table 1).

As the sample design was not stratified by social factors it would seem desirable to control for these statistically. Doing so reveals that, for example, in households where fewer than half of the adult members have achieved the middle school level of education, basic knowledge of symptoms is still further enhanced by the intensive education programme (though the effect in the better-educated households is unclear); medium level knowledge is also better in the experimental zone after general education controls are made. Similar findings are made regarding the knowledge that leprosy is caused by a 'germ': the differences between the zones are large, and statistically significant in the case of the less educated households (Table 2). This pattern of the superiority of the experimental zone over the control tends to repeat itself for most items of knowledge and is robust against the effect of general education differentials.

Respondents were canvassed on their attitude to different aspects of the disease: here responses from the patients proved most conclusive, with their willingness to accept the diagnosis and their confidence in the cure both being significantly enhanced by the intensive educational programme in comparison with the survey method (Table 3 ). This is a clear indicator of the better motivation achieved when patients have been identified by themselves (or their peers) rather than by visiting paramedics. Again the observation remains valid when controls for general educational attainment are introduced. However, some care in interpretation is needed here, in that a small proportion of patients will have

Table 1. Medium-level perception of symptoms by zone

\begin{tabular}{lccc}
\hline & \multicolumn{3}{c}{ Zone } \\
\cline { 2 - 3 } & $\mathrm{M}$ & $\mathrm{L}$ & Total \\
\hline Knowledge & 46 & 77 & 123 \\
& $(23 \cdot 0)$ & $(38 \cdot 5)$ & $(30 \cdot 7)$ \\
Rest & 154 & 123 & 277 \\
& $(77 \cdot 0)$ & $(61 \cdot 5)$ & $(69 \cdot 3)$ \\
\hline Total & 200 & 200 & 400 \\
& $(100 \cdot 0)$ & $(100 \cdot 0)$ & $(100 \cdot 0)$ \\
\hline
\end{tabular}

Difference between zones is significant at $5 \%$ level. 
Table 2. Knowledge of germ according to educational composition of household

\begin{tabular}{lccc}
\hline & \multicolumn{3}{c}{ Zone } \\
\cline { 2 - 3 } & M & L & Total \\
\hline Less than 50\% of educated adults in household & \\
Knowledge of germ & 14 & 15 & 29 \\
& $(11 \cdot 2)$ & $(22 \cdot 7)$ & $(15 \cdot 2)$ \\
No knowledge & 111 & 51 & 162 \\
& $(88 \cdot 8)$ & $(77 \cdot 3)$ & $(84 \cdot 8)$ \\
\hline Total & 125 & 66 & 191 \\
& $(100)$ & $(100)$ & $(100)$ \\
\hline & & & \\
More than 50\% of educated adults in household & \\
Knowledge of germ & 18 & 47 & 65 \\
& $(25 \cdot 0)$ & $(36 \cdot 4)$ & $(32 \cdot 3)$ \\
No knowledge & 54 & 82 & 136 \\
& $(75 \cdot 0)$ & $(63 \cdot 6)$ & $(67 \cdot 7)$ \\
\hline Total & 72 & 129 & 201 \\
& $(100)$ & $(100)$ & $(100)$ \\
\hline
\end{tabular}

Difference between zones is significant at $5 \%$ level in the lesser educated group. Difference between educational levels is also significant at $5 \%$ level.

already suffered some deformity, so that the concept of cure will have had some ambiguity for them since chemotherapy cannot repair the damage already done.

As far as practice is concerned, our questions were confined to eliciting information on how far people looked for symptoms in each other and motivated clinic attendance in suspected patients. Here the superiority of the experimental zone failed to emerge. However, $30 \%$ of patients in that zone claimed to have been motivated in that way

Table 3. Confidence of patients in cure

\begin{tabular}{lccc}
\hline & \multicolumn{2}{c}{ Zone } & \\
\cline { 2 - 3 } & $\mathrm{M}$ & $\mathrm{L}$ & Total \\
\hline Confident of cure & 71 & 84 & 155 \\
& $(72 \cdot 4)$ & $(88 \cdot 4)$ & $(80 \cdot 3)$ \\
Not confident & 27 & 11 & 38 \\
& $(27 \cdot 6)$ & $(11 \cdot 6)$ & $(19 \cdot 7)$ \\
\hline Total & 98 & 95 & 193 \\
& $(100 \cdot 0)$ & $(100 \cdot 0)$ & $(100 \cdot 0)$ \\
\hline
\end{tabular}

Difference between zones is significant at $5 \%$ level. 
(against only $11 \%$ in the control zone). It is possible that those motivating, though no greater in number, were more active and successful in $\mathrm{L}$ zone.

In some cases the superiority of the intensive education method was enhanced or diminished by other characteristics of the individuals surveyed (besides zonal residence). For example, overall educational attainment by adult members of the household nearly always strengthened the effect of the experimental method in imparting knowledge and in improving attitudes (see, for example, Table 2). More strikingly, relevant knowledge was increased by the presence of school-attendant children in the household, often compensating for the effect of lack of parental education. The sex of the respondent was another important differentiating characteristic. Women were in possession of less of the relevant knowledge than were men, even in the experimental zone.

\section{Discussion}

It should be stressed that this evaluation was not intended to test the superiority of casedetection in the experimental zone. Its purpose was purely to see whether the same levels of public awareness would be achieved by the cost-saving experiment of an intensive community-level educational approach in place of the laborious door-to-door survey technique. In fact both patients and non-patients who were subjected to the educational experiment showed superior awareness of important facts relevant to the prevention, cure and social understanding of the nature of the disease. This should constitute a step on the road towards the ultimate removal of stigma. Furthermore, since a higher proportion of those in the experimental zone claimed they were convinced that treatment would be effective, there is some reason to expect that non-compliance would be reduced. Some of the recent literature has linked compliance to the quality of information that is provided to the patient. ${ }^{7}$ The outcome of our study has prompted ALERT-India to enhance the educational component in its existing survey programme.

The question may be raised, however, as to whether appropriate personnel would be readily available to replace the survey technique comprehensively with an intensive educational programme. The ALERT experiment drew on the existing skills of its health educators, and simply used more intensively the educational materials they already possessed. Our view (which in essence is shared by others) ${ }^{8}$ is that at least the more experienced members of the existing paramedical corps could be adopted as health educators in the programme; they would need to be equipped with additional educational materials which would add to the resource cost, but only as a one-off expenditure. This would create a two-tier structure of paramedics, which would have the added advantage of offering promotional prospects as an incentive for the greater involvement of new recruits in the wider aims of the organization: by developing their understanding of and ability to interact with the community, rather than simply acquiring skills in case detection and delivery of curative services, they would be securing a career for themselves as a valuable cadre of health educators. At the same time, this awareness would ensure some much needed variety in the activities and career structure of paramedics, for whom the repeated combing of vast urban slums for new and recalcitrant patients is a tedious chore, as detrimental to the motivation of paramedics as to the compliance of their patients. ${ }^{9}$

Finally our study brings out the importance of seeking to involve specifically both 
women and children in any health education programme. The less informed responses of women in both our zones underlines how any programme of information that relies upon the spontaneous attendance of women is likely in most cultures effectively to discriminate against women: special programmes for women's groups and appropriate timings for women to attend would seem to be the solution. At the same time, the fact that better informed respondents came from households where school-attending children were present suggests the value of carrying out leprosy education work in schools, especially in urban settings where attendance is high.

\section{Acknowledgments}

The authors are indebted to Dr A Colin McDougall for much helpful advice on the presentation of this material: the views expressed here, however, remain the authors' alone. The School of Oriental and African Studies is grateful to the Gatsby Charitable Foundation for its support; and ALERT-India is similarly grateful to the Damien Foundation.

\section{Ref erences}

I Samy AA, Mancheril J, Manek KP, McDougall AC. ALERT-India 1981-1989: 9 years experience of leprosy control in the slums of Bombay (in preparation).

2 Dharmendra (ed.). Leprosy, Volume II. Bombay: Samant, 1985.

3 Ganapati R, Revankar CR, Dongre VV. Prevalence of leprosy in slums in Bombay including a leprosy colony. Int J Lepr 1985; 57: 383-8.

${ }^{4}$ Revankar CR, Dudhalkar B, Raja GD, Ganapati R. Leprosy survey in urban slums: possibilities for epidemiological investigations. Lepr Rev, 1982; 53: 99-104.

5 Leprosy: status report 1985-86. National Leprosy Eradication Programme in India, 1986. Leprosy Division, Directorate General of Health Services, Ministry of Health and Family Welfare, Delhi.

6 Ramasubban R, Crook N, Singh B. Educational approach to leprosy control: an evaluation of knowledge, attitudes and practice in two poor localities in Bombay. Centre for Social and Technological Change, Bombay, 1990.

7 Mull JD, Wood CS, Gans LP, Mull DS. Culture and 'compliance' among leprosy patients in Pakistan. Soc Sci Med, 1989; 29: 799-811.

8 Van Parijs LG. Re-defining health education in leprosy: a personal view. Lepr Rev 1990; 61: 145-50.

9 Ramasubban R, Singh B, Crook N. Paramedics as Prometheans? A study of leprosy control in Bombay. Technical paper, Centre for Social and Technological Change, Bombay, 1990. 


\title{
Le contrôle de la lèpre grâce à l'éducation: une évaluation des connaissances, des attitudes et des habitudes dans deux localités pauvres de Bombay en Inde
}

\author{
N. Crook, R Ramasubban, A Samy et B Singh
}

Résumé Estimant qu'un programme éducatif bien conçu sur la lèpre donnerait des meilleures informations en matière de connaissances, d'attitudes et de dépistage des cas de lèpre que celles obtenues par les enquêtes traditionnelles à grande échelle, ALERT-India a lancé en février 1985 un programme de comparaison des deux méthodes dans le quartier S de Bombay. Un programme intensif de 12 mois d'éducation sanitaire faisant appel à des équipes entraînées fut organisé dans une zone du quartier. Huit mois plus tard, une étude à grande échelle (faite régulièrement dans tout le pays les années précédentes) fut menée dans une zone voisine. En 1987, le Centre pour le Changement social et technologique à Bombay en association avec la faculté des études orientales et africaines de l'Université de Londres fut prié d'évaluer l'effet du programme éducatif en matière de connaissances, d'attitudes et d'habitudes dans les zones d'essai et de contrôle. Les autres aspects de cette expérience y compris son coût et son efficacité en matière de dépistage des cas de lèpre, seront publiés séparément. Le rapport décrit la méthode d'évaluation des connaissances, des attitudes et habitudes ainsi que les contrôles sociaux et environnementaux inclus dans l'analyse statistique. Les résultats révèlent une ignorance profonde de la lèpre et de son traitement dans les zones faisant l'objet de l'étude et dans les zones de contrôle. La connaissance des premiers symptômes était particulièrement faible et à tout égard, les scores des femmes étaient constamment inférieurs à ceux des hommes. L'éducation générale favorisait l'assimilation de connaissances spécifiques et l'éducation des enfants compensait le manque d'éducation des parents dans ce domaine. Dans l'ensemble, l'évaluation indiquait que les résultats du programme intensif d'éducation étaient supérieurs à ceux de l'étude à grande échelle en matière d'élargissement des connaissances, d'attitudes et d'habitudes.

\section{Un enfoque educacional del control de la lepra; una evaluación del conocimiento, actitudes y práctica en dos localidades pobres de Bombay, India}

\author{
N Crook, R RamasubBan, A Samy y B Singh
}

Resumen Basándose en la hipótesis de que un enfoque educacional sistemático y cuidadosamente planeado de la lepra podria producir resultados superiores, en términos de conocimiento, actitudes y presentación de casos, a aquellos de los métodos de estudios en masa tradicionales y ya establecidos, ALERT-India lanzó un programa en el distrito S de Bombay en febrero de 1985, para comparar los dos métodos. Se llevó a cabo un programa intensivo de educación en la salud, usando grupos entrenados en una zona de este distrito durante un periodo de 12 meses. Ocho meses más tarde, se llevó a cabo un estudio en masa en una zona adyacente (como se usó en forma rutinaria en los años previos y basado en todo el país). En 1987, se le solicitó al Centro para Cambio Social y Tecnológico de Bombay, en conjunto con la Escuela de Estudios Africanos y Orientales, Universidad de Londres, que evaluaran el ef ecto del enfoque educacional mencionado arriba en términos de conocimiento, actitudes y práctica en las dos zonas, en la de control y en la en estudio. Otros aspectos de este enfoque experimental, incluyendo su costo y eficacia en identificar casos de lepra será publicado separadamente. Se describe el diseño de la evaluación 'KAP' y los controles sociales y medio ambientales introducidos en el análisis estadistico. Los resultados indican un considerable grado de ignorancia acerca de la lepra como una enfermedad (y su tratamiento) en ambas zonas, en la en estudio y en la control. El conocimiento acerca de los primeros síntomas fue particularmente pobre y en todos los aspectos las mujeres consiguieron invariablemente menos puntos que los hombres. La educación general mejoró la absorción de conocimiento específico, y la educación de los niños compensó en forma adecuada por la falta de educación de los padres en este aspecto. La evaluación, en forma completa, indicó que el enfoque educacional intensivo fue superior al enfoque de estudio en masa en términos de un conocimiento, actitudes y práctica mejoradas. 